\title{
ROSALIE
}

\section{The brazilian female monkey of Charcot}

\author{
Hélio A.G. Teive', Walter O. Arruda', Lineu C. Werneck²
}

\begin{abstract}
Jean-Martin Charcot, the father of Neurology, a very austere and resened man that did not express affection freely for human being, had a profound affection to animals, particularly to a small female monkey, called "Rosalie", which came from Brazil and was a gift of Dom Pedro II to Charcot.

KEY WORDS: Charcot, female monkey, "Rosalie", Brazil.
\end{abstract}

\begin{abstract}
Rosalie: a pequenina macaca brasileira de Charcot
RESUMO - Jean-Martin Charcot, considerado o pai da Neurologia, foi um homem de aspecto austero e reservado,que tinha dificuldades de expressar os seus sentimentos para outros seres humanos. Contudo ele tinha profunda afeição por animais, particularmente por uma pequena macaca, chamada de "Rosalie", oriunda do Brasil e que foi um presente dado a ele por Dom Pedro II.
\end{abstract}

PALAVRAS-CHAVE: Charcot, macaca, "Rosalie", Brasil.

Jean-Martin Charcot (1825-1893), the father of Neurology, was the first professor of nervous system diseases in a formal way. He studied as vast array of neurological diseases and gave classical description' (Fig 1). Charcot created the famous anatomo-clinical method, where he examined the patients and focused on clinical nosography and classification and then, after the patient's death, in the autopsy, he analysed anatomic lesions, both macro- and microscopically ${ }^{2}$.

Despite his studies with human autopsies, Charcot never allowed vivisection of animals at the Salpetrièrés hospital and he had a passionate affection for animals, particularly dogs and a small monkey. Two dogs, "Carlo", the Labrador, and "Sigurd", a big one dog, were close animals, but the favorite pet of Charcot was a small female monkey named "Rosalie" $2-5$.

\section{CHARCOT AND "ROSALIE"}

Charcot and Dom Pedro II, Brazilian Emperor, were related in both social (close friends) and medical terms (patient-physician relationship). Dom Pedro II had an affection to animals that was deeply shared by $\mathrm{Charcot}^{1-5}$. Historical data confirm that the small female monkey that lived at Charcot's house came from Brazil and was a gift of Dom Pedro II to Charcot ${ }^{3-7}$.

Charcot, that was austere and reserved man that did not express affection freely for human being, had a profound affection to this small female monkey, called "Rosalie"2. This kind of monkey is very commom in Brazil and belongs to Cebidae fami ly, Cebinae sub-family, probably genus Cebus sp or Cebus apella. They have peculiar aspect (head and tail) and are very agile jumpers, runners, swinging and leaping through trees. They are very smart, funny, lovely and friendly also (Fig 2).

According Guillain's biography of Charcot, "Rosalie" stayed togheter to Charcot at table during his meals and Charcot took care of her food, laughed with her, and was delighted when she snatched a nut or a banana from his own plate $^{3}$. In a paper published by Guinon, after Charcot's death, the author comment: ...Um singe, câline comme ume chatte, prope comme um sou. Le patron l'aimat beacoup et il s'amusait de toutes sesfarces. Il lui avait ménage une place 'a table 'coté de lui, sur une chaise d'enfant 'a tablete, et il était ravi quand "Rosalie" lui chipat une noisette ou une Neurology Service, Internal Medicine Department, Hospital de Clínicas, Federal University of Paraná, Curitiba PR, Brazil (UFPR):
'Assistant Professor of Neurology, UFPR; ${ }^{2}$ Head of Neurology Service, Hospital de Clínicas, UFPR.

Received 3 March 2005. Accepted 29 April 2005.

Dr. Hélio A.G. Teive - Rua General Carneiro 1103 / 102 - 80060-150 Curitiba PR - Brasil. E-mail: hagteive@mps.com.br 


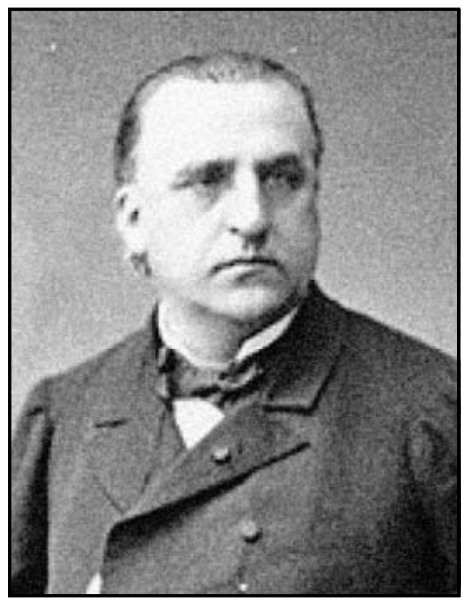

Fig 1. Jean-Martin Charcot (1825-1893) (Extracted from http://webperso. easycon nect.fr/baillement/ images/ charcot.gif) friandise dans son assiette, ou, observant le mo ment óu on ne la regardait pas, allait du bout de sa queue prévaler une banana dans un compoti er. Et alors le patron riait, de ce rire silencioux qui secouait ses joues, sa poitrine et toute sa person ne et qui animait et éclairait subitement son regard habituellment concentré...4.

In his famous book about Charcot, Goetz, Bonduelle and Gelfand comments a tale recalled by Charcot granddaughter, about the affair with the small female monkey during a dinner in Charcot's house, with the presence of several famous persons, including the Grand Duke of Russia. "Rosalie" dismantled the dinning room (a elaborate fruit decoration in the dining room centerpiece), but Charcot and the guest friends maintained a good sense of humor ${ }^{2}$.

In conclusion, Charcot, that was austere and reserved man that did not express affection freely for human being. Had a profound affection to animals, particularly to a small female monkey, called "Rosalie", that came from Brazil and was a gift of Dom Pedro II to Charcot ${ }^{2-7}$.

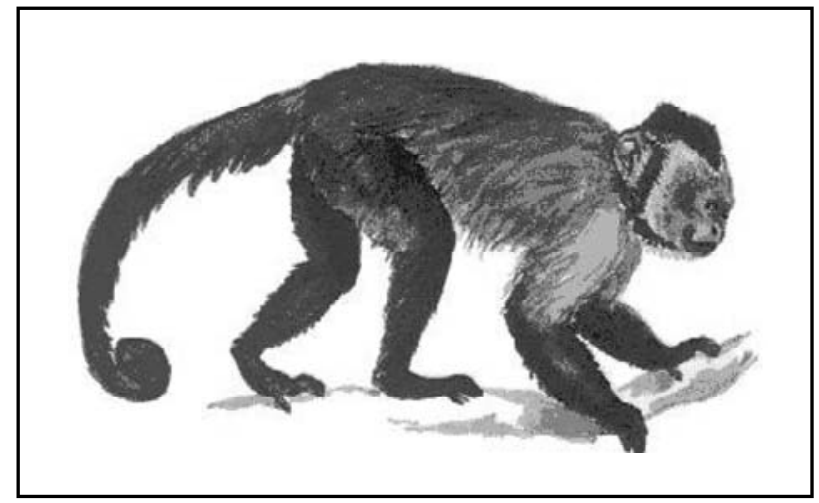

Fig 2. Cebus Apella. Black-capped Capuchin (Extracted from hometown.aol.com/ darwinpage/zoo/peru2.htm).

Acknowledgment - The authors thanks to Professor Rogério Ribas Lange (Faculdade de Medicina Veterinária da UFPR, Curitiba/PR), Professor José Américo de Oliveira (Faculdade de Odontologia de Araçatuba/SP), Professor Luiz A. de Lima Rezende (UNESP, Botucatu/SP), Professor Andrew J. Lees (National Hospital for Neurology and Neurosurgery, Queen Square, London, UK) and Professor Christopher G. Goetz (Rush University Medical Center, Chicago, IL, USA).

\section{REFERENCES}

1. Teive HAG, Almeida SM, A r ruda WO, Sá DS, Werneck LC. Charc ot and Brazil. Arq Neuro-psiquiatr 2001;59:295-299.

2. Goetz CG, Bonduelle M, Gelfand T. Charcot: constructing neurology. New York: Oxford Univ Press, 1995:271-272.

3. Guillain G. JM Charcot: his life-his work. New York: Paul B. Hoeber, 1959:16-29.

4. Guinon G. Charcot intime. Paris Medical, 1925; Mai 23:511-516.

5. Souques A. Charcot intime. Presse Med 1925;42:693-698.

6. Soublin J. D. Pedro II: o Defensor Perpétuo do Brasil. Memórias imaginárias do último Imperador. São Paulo: Editora Paz e Terra, 1997.

7. Calmon P. História de Dom Pedro II. Rio de Janeiro: Livraria José Olímpio Editora/MEC, 1975.

8. Nowak RM. Mammals of the Wo rd. Fifth Edition, Volume I, Baltimore The Johns Hopkins Univ Press, and London, 1991:461-446. 